\title{
Narratologische Konzepte des grenzwertigen Erzählens
}

Die Analyse ausgewählter Werke von Robert Walser, Theodor Fontane und Franz Kafka hat deren narrative und ambivalente Auseinandersetzung mit Ordnung aufgezeigt. Während Kafkas und Walsers Erzählen sich als unzuverlässig, inszeniert und aporetisch erweist, indem es eine durchgängige story verweigert und Konventionen der Kohärenz, Kausalität und Zeitstruktur verletzt, subvertiert Fontane Erzählmodelle durch einen untergründig geführten Ordnungsdiskurs und die ausgestellte Kontrolle von Ambivalenz. Diese Erzählformen werden hier als prekäres Erzählen konzeptualisiert. Aus einer theoretischen Perspektive stellt sich nun die Frage, ob diese Verunsicherungen der Ordnung des Erzählens überhaupt noch als Erzählen gelten soll. ${ }^{557}$

Wurde bislang lediglich Bezug genommen auf Seymour Chatmans Texttypen-Theorie ${ }^{558}$, stehen im Folgenden neuere narratologische Ansätze im Zentrum, die sich dezidiert den Grenzen des Erzählens und grenzwertigem Erzählen widmen. So kann die Theoriedebatte zielgerichtet zum Zweck einer stärkeren Konturierung des prekären Erzählens im Kontext der zeitgenössischen Narratologie geführt werden. ${ }^{559}$

557 Vgl. dazu eines der sechs „Dilemmas“, die sich bei der Definition des Begriffs „narrative“ stellen: „Should a definition of narrative give equal status to all works of literary fiction, or should it regard certain types of postmodern novels (and films) as marginal? In other words, does an avant-garde text that refers to characters, settings, and events, but refuses to organise these contents into a determinate story expand the meaning of narrative, making it historically variable, or does it simply demonstrate the separability of the concepts of ,literature', ,narrative', and ,fiction'?" Marie-Laure Ryan, „Narrative“, in Routledge Encyclopedia of Narrative Theory, hg. von David Herman, Manfred Jahn und Marie-Laure Ryan (London: Routledge, 2010), 346.

558 Siehe Kap. 3.1.1 Erzählen - Beschreiben - Argumentieren (Chatman), S. 97ff. oben.

559 Die Narratologie erlebt seit Mitte der goer-Jahre einen regelrechten Boom. Es kann hier nicht darum gehen, einen erschöpfenden Überblick über die Definitionen von Erzählen und Erzählung zu liefern. Stattdessen stehen ausgesuchte, postklassische Positionen im Zentrum, die für das prekäre Erzählen, wie es in den Textanalysen in induktiv ausgerichteter Weise erarbeitet wurde, von unmittelbarem Wert sind. Es gibt zahlreiche sehr gute Einführungen in die Narratologie, deren aktuelle Entwicklungen und Spezialprobleme. In mehreren Auflagen erschienen sind: Monika Fludernik, Einführung in die Erzähltheorie, Einführung Literaturwissenschaft (Darmstadt: WBG, 2006); Martinez und Scheffel, Einführung in die Erzähltheorie; Köppe und Kindt, Erzähltheorie. 
Mit Marie-Laure Ryans Studie Modes of Narrativity wird ein Versuch vorgestellt, wie Narrativität analog zu Gérard Genettes Modi des Erzählens in verschiedenen Graden konzeptualisiert werden kann. Monika Fluderniks Konzept der, natural' narratology liefert ein kognitives Modell, das es ermöglicht, mittels narrativization Texte als Erzählungen zu rezipieren, die konventionelle frames des Narrativen nicht aktivieren. Die unnatural narratology schließlich stellt dezidiert Texte in den Vordergrund, die Erzählkonzepte herausfordern, ohne die Widersprüche der Texte vorschnell aufzulösen. Das Kapitel schließt mit einer Diskussion des Begriffs der antinarratives und deren Bezug zum prekären Erzählen.

\subsection{Modes of Narrativity (Ryan)}

Es scheint auf der Hand zu liegen, dass Narrativität eine skalare Eigenschaft ist, die unterschiedlich stark ausgeprägt sein kann. ${ }^{560}$ Entsprechend würden

Den Begriff der "postclassical narratology“ hat David Herman geprägt. Einen guten Überblick bietet der Band Alber und Fludernik, Postclassical Narratology. Vgl. auch Tom Kindt und Hans-Harald Müller, Hrsg., What is Narratology? Questions and Answers Regarding the Status of a Theory (Berlin, Boston: De Gruyter, 2003). Darin besonders: Nünning, „Narratology or Narratolgies?“; Gerald Prince, „Surveying Narratology“, in What is Narratology? Questions and Answers Regarding the Status of a Theory, hg. von Tom Kindt und Hans-Harald Müller, Narratologia. Contributions to Narrative Theory 1 (Berlin, Boston: De Gruyter, 2003), 1-17. Ein Advokat der strukturalistisch ausgerichteten Narratologie ist Meister, „Narratology as Discipline. A Case for Conceptual Fundamentalism“.

56o Wolf Schmid spricht von narrativen Texten in einem engeren und weiteren Sinn: Unter narrativen Texten in einem weiten Sinn fasst er mimetische Texte, die ohne vermittelnde Erzählinstanz funktionieren (dramatische Texte, Comics, Film und andere) und unterscheidet weiter zwischen deskriptiven Texten und einer nicht weiter differenzierten Restklasse. Die narrativen Texte in einem engeren Sinn zeichnen sich gemäß Schmid durch eine vermittelnde Erzählinstanz aus. Im Zentrum dieser Vermittlung steht die Geschichte als eine Reihe von verknüpften Ereignissen. Ereignisse wiederum definiert Schmid als Zustandsveränderungen, die einen Katalog von Bedingungen erfüllen müssen. Vgl. Schmid, Elemente der Narratologie, 1-26. In der bei Kafkas Bau dominanten Iterativität sieht er ein Ausschlusskriterium. Vgl. Schmid, 18. Dass das Vorhandensein einer illusionistischen Erzählinstanz den Grad der Narrativität beeinflussen muss, kann bestritten werden. Vgl. dazu Nünning, „Metanarration“; Nünning, „Mimesis des Erzählens“.

Es gibt auch Versuche, die Grenzen des Erzählens über die Medialität zu bestimmen und hierbei der schriftlichen Erzählung einen prototypischen Stand zuzuschreiben. Diese Dimension ist für die vorliegende Arbeit nicht relevant, da es hier ausschließlich um schriftliche Texte geht, die Mündlichkeit zwar inszenieren, jedoch in ihrer Medialität schriftlich bleiben. Vgl. zur Debatte um eine mediensensitive Narratologie: Marie-Laure Ryan und Jan-Noël Thon, Hrsg., Storyworlds Across Media. Toward a media-conscious Narratology (Lincoln, London: University of Nebraska Press, 2014). 
Texte, wie die hier behandelten, die die klassischen Erzählordnungen subvertieren, bloß über eine geringe Narrativität verfügen. Marie-Laure Ryan schlägt verschiedene Modi von Narrativität vor, die formalistischen Konzepten, wie der Idee einer minimal story, dennoch verbunden bleiben. ${ }^{561}$ In ihrem einflussreichen Aufsatz The Modes of Narrativity and Their Visual Metaphors entwickelt sie einen Katalog von einem Dutzend narrativer Modi. ${ }^{562}$ Mit den verschiedenen Modi der Narrativität versucht Ryan gleichsam auf der storyEbene das Gegenstück zu Genettes auf die discourse-Ebene bezogenen Modi des Erzählens zu erarbeiten.

Als prototypisch für die „narrative family“ und am eindeutigsten erzählerisch definiert Ryan die "simple narrativity“.563 Darunter versteht sie einfache Märchen, Anekdoten, „urban legends“, die Erzählungen aus dem Decamerone und Witze, die nicht auf Sprachwitz beruhen: „In simple narrativity, the semantic content of the text is a plot and little else. The plot resolves around a single problem, punch line, or point and ends when the problem is resolved, the punch line delivered, or the point demonstrated."564 Werden mehrere solcher einfachen Erzählungen aneinandergehängt, wie im Decamerone oder den Märchen aus 1001 Nacht kann man mit Ryan von multiple narrativity sprechen. Vielfältigere Verknüpfungsformen der Erzählungen definiert sie als complex narrativity. Darunter zählt sie die Romane Balzacs, Zolas, Flauberts, Dostojewskis und Dickens'. Im Erzählmodus dieser Texte sind die „units“, womit Ryan die Mikroerzählungen (Binnenerzählungen) meint, stärker in die Makroerzählung eingebunden.

Die ersten drei narrativen Typen in Ryans Konzept sind durch die Komplexität der story geprägt, respektive durch deren integrative Kombination von Mikro- und Makroerzählung. Den ersten Modus, in dem Ryan eine Schwächung von Narrativität ausmacht, nennt sie die proliferating narrativity: Die Mikroerzählungen sind ausufernd und lassen sich nicht mehr in eine übergeordnete Makroerzählung einbinden. Der Fokus bei diesen "picaresque, chatty novels“

561 In seinem Dictionary of Narratology definiert Gerald Prince die „minimal story“ wie folgt: „A narrative recounting only two states and one event such that (1) one state precedes the event in time and the event precedes the other state in time (and causes it); (2) the second state constitutes the inverse (or the modification, including the ,zero modification) of the first. John was happy, then he saw Peter, then, as a result, he was unhappy' is a minimal story." Prince, A Dictionary of Narratology, 53. Ein "minimal narrative" besteht aus einem einzelnen Ereignis. Prince spricht auch davon, dass „narrativity“ auf den „formal and contextual features making a narrative more or less narrative" gründet und impliziert also ebenfalls eine Skalarität von Erzählhaftigkeit. Prince, 64 .

562 Ryan, „The Modes of Narrativity and Their Visual Metaphors“.

563 Ryan, 371.

564 Ryan, 371f. 
„does not reside in the building and resolution of dramatic suspense spanning the entire text, but in the narrative verve displayed in the accumulation of little stories. “565 Es wird hier also der Erzählakt (die „narrative verve") hervorgehoben und auf die discourse-Ebene verwiesen. An diesem Zitat ist die Problematik abzulesen, die sich aus Ryans Ansatz hinsichtlich story und discourse ergibt: Sie will die graduellen Abstufungen der Narrativität über story definieren, kommt aber nicht um die Vermittlungsebene („narrative verve“) herum. Dies ist insofern problematisch, als Ryan explizit einen Ansatz vertritt, der eine klare Trennung zwischen story und discourse anstrebt. Ryans Beschreibung des Modus der proliferating narrativity erinnert stark an das discourse-Phänomen Digression. In digressiven Texten sind die Figuren ebenfalls weniger als solche wichtig, denn in ihrer Funktion, die Mikroerzählungen zu verknüpfen.

Die nächste Stufe in Ryans Modell abnehmender Narrativität ist die diluted narrativity, die „verwässerte Narrativität", als deren Vertreter sie die Klassiker der Erzählkunst („classics of the narrative genre“566) nennt: Flauberts Madame Bovary, Tolstois Krieg und Frieden, Prousts À la recherche du temps perdu.

Far from forming the sole focus of interest, the plot of the diluted narrative competes for attention with nonnarrative elements such as extended descriptions, metanarrative comments, digressions, narratorial and authorial interventions, general considerations, and philosophical meditations. ${ }^{567}$

Die „nonnarrative elements“, die Ryan hier als Konkurrenz zum "plot“ bezeichnet, scheinen im Grunde allesamt Phänomene der Digression zu sein. Der Weg von den ,hoch-narrativen' Erzählungen zu denjenigen mit schwacher Narrativität präsentiert sich bei Ryan als zunehmende Digression: Digression und Erzählhaftigkeit begrenzen einander. In der diluted narrativity geht es gemäß Ryan weniger um die story als darum, die Atmosphäre zu spüren und den Charakteren nahezukommen: „While the highly narrative text keeps the reader looking ahead, the text of diluted narrativity invites her to linger on the scene, to step outside narrative time. ${ }^{458}$ Auch hier baut Ryan ihr Argument über den discourse auf, ist die Pause als Heraustreten aus der story doch ein discourse-Effekt. Nichtsdestotrotz hat die diluted narrativity nach wie vor ein konkretes erzählerisches Ziel, nämlich das Darstellen und Erfahrbarmachen einer Atmosphäre und der Charaktere.

\footnotetext{
565 Ryan, 374.

566 Ryan, 375 .

567 Ryan, 375 .

568 Ryan, 375 .
} 
Die embryonic narrativity verliert weiter an Narrativität. Events fehlen ganz oder werden kaum mehr oder nur durch bloße Aufzählung aneinandergehängt. Das „complex network of logical relations“ 569 fehlt, das gemäß Ryan die events zu einem intelligiblen Plot zusammenfügt.

Den nächsten Modus gegen Ende der Skala der Narrativität nennt Ryan underlaying narrativity. Hier wird nur noch das Rohmaterial geliefert, das der Rezipient zu einer sinnhaften Erzählung zusammenfügen muss.

Ryans Katalog kulminiert schließlich in der antinarrativity. Zwar sind narrative Elemente vorhanden, sie können aber nicht in eine stabile Lektüre überführt werden: „[T]he reader of the antinarrative text recognizes narrative elements, such as characters, actions, and a reference world, but she cannot fit these items into the network of a stable and comprehensive narrative interpretation. “570

Scheinen Ryans Modi zunächst plausibel, so stellt sich doch die Frage nach der Zuteilung. Distinkte Eigenschaften der Erzählungen, die sie einem der Modi zuordnen würden, sind kaum oder im Übermaß vorhanden. ${ }^{571}$ Auf ihrer Skala der Narrativität beruht auch Ryans Vorschlag zur Definition des Narrativen. Sie wehrt sich gegen binäre Definitionen und vertritt ein „fuzzy set" von prototypischen Bedingungen, aus denen die passenden Konzepte zusammengestellt werden können. ${ }^{572}$ Für das prekäre Erzählen scheint Ryan zunächst eine geeignete Kontextualisierung anzubieten.

\section{Ryan, 376.}

570 Ryan, 379 .

571 Vgl. dazu auch Brian McHale, der in einer Studie zur Narratologie der Lyrik Mühe hat, die lyrischen Arten des Erzählens den Kategorien Ryans zuzuordnen. Ryans „antinarrativity“ bezeichnet er als "grab-bag“, was hinsichtlich der Breite dieser Kategorie sicherlich zutreffend ist. Er schlägt stattdessen, ohne selbst präzise zu sein, den Begriff der „weak narrativity“ vor. Brian McHale, "Weak Narrativity. The Case of Avant-Garde Narrative Poetry“, Narrative 9, Nr. 2, (2001): 165. „Weak narrativity involves, precisely, telling stories ,poorly, distractedly, with much irrelevance and indeterminacy, in such a way as to evoke narrative coherence while at the same time withholding commitment to it and undermining confidence in it; in short, having one's cake and eating it too." Brian McHale, 165. Hervorhebung i. O.

572 „Rather than regarding narrativity as a strictly binary feature, that is, as a property that a given text either has or doesn't have, the definition proposed below presents narrative texts as a fuzzy set allowing variable degrees of membership, but centered on prototypical cases that everybody recognizes as stories.“ Ryan, „Toward a Definition of Narrative“, 28. Diese verschiedenen Kategorien von Raum, Zeit, kognitiven, formalen und pragmatischen Dimensionen bieten Raum für unterschiedliche Akzentuierungen in der Definition des Erzählens. Es liegt auf der Hand, dass die Verabschiedung einer binären Definition, die der Vielfalt der Ausformungen des Erzählens nicht gerecht werden kann, viele Vorteile 
Jedoch stellt es sich als schwierig heraus, Ryans Modi Fontane, Walser und Kafka zuzuordnen. Sowohl bei Walser wie bei Fontane kann von einer proliferating narrativity gesprochen werden, insofern als es zahlreiche Mikroerzählungen gibt, die bei Fontane mit der Künstlichkeit der Erzählstimme geordnet und bei Walser dem Erzählfluss überlassen werden. ${ }^{573}$ Die diluted narrativity scheint auf Fontane und Kafka zu passen, da bei beiden die Darstellung der Ordnung, die Figuren und die Atmosphäre im Zentrum stehen. Außen vor jedoch bleibt dabei die Künstlichkeit von Fontanes Ordnung und die Paradoxie von Kafkas Erzählens. ${ }^{574}$ Schließlich weisen alle drei auch Elemente der embryonic narrativity auf, die insbesondere bei Walser augenfällig ist. ${ }^{575}$ Die antinarratives werden später auch eine wichtige Position bei der unnatural narratology einnehmen und mit Bezug zum prekären Erzählen gesondert diskutiert. ${ }^{576}$ Der Fokus auf die klassische Erzählordnung, die sich am Märchen und der story als Definiens von Erzählen orientiert, schränkt Ryans Konzept stark ein.

bringt. Damit einher geht ebenso offenbar der Nachteil, dass keine Einheitlichkeit geschaffen werden kann. Für eine Diskussion über die Möglichkeiten und Grenzen dieser Definitionsstrategie von Narrativität vgl. die Diskussion zwischen Ryan und Rudrum, wobei letzterer mit Wittgensteins Sprachspiel- und Familienähnlichkeits-Konzept auf die Bedeutung der pragmatischen Dimension hinweist: David Rudrum, „From Narrative Representation to Narrative Use: Towards the Limits of Definition“, Narrative 13, Nr. 2 (2005): 195-204, https://doi.org/10.1353/nar.2005.0013; Marie-Laure Ryan, „Semantics, Pragmatics, and Narrativity: A Response to David Rudrum“, Narrative 14, Nr. 2 (2006): 188-196; David Rudrum, „On the Very Idea of a Definition of Narrative: A Reply to MarieLaure Ryan“, Narrative 14, Nr. 2 (2006): 197-204.

Vgl. auch die "fuzziness“ der Definition der Narrativität, die Abbott betont. Porter H. Abbott, „Narrativity“, in The Living Handbook of Narratology, hg. von Peter Hühn u. a. (Hamburg: Hamburg University, 2018), http://www.lhn.uni-hamburg.de/article/narrativity.

573 Samuel Frederick benutzt den Begriff der "narrative proliferation“ für Walser. Er sieht in der apophatic narration, also den vielfach angefangen, bloß möglichen und negierten Erzählfragmenten bei Walser die Ursache der narrativen Wucherung. Frederick, Narratives Unsettled, ${ }_{36-56 .}$

574 Vgl. zum ungeklärten Status des Erzählers bei Kafka auch Brian Richardson, „Narrative Poetics and Postmodern Transgression. Theorizing the Collapse of Time, Voice, and Frame“, Narrative 8, Nr. 1 (2000): 23-42.

575 Vgl. auch hier die apophatic narration bei Frederick, die mit Ryan als embryonic narrativity zu beschreiben wäre. Frederick, Narratives Unsettled, 42.

576 Siehe Kap. 5.4 Antinarratives?, S. 263ff. unten. 


\section{$5.2 \quad$,Natural' Narratology (Fludernik)}

Monika Fludernik geht Erzählen in ihrem Buch Towards a,Natural' Narratology, das 2016 sein zwanzigjähriges Erscheinen feierte und als eines der Gründungsdokumente der kognitiven Narratologie gilt, in dezidierter Opposition zum story-Begriff an. ${ }^{577}$ Für sie steht das Kriterium der experientiality im Zentrum, der Begriff anthropomorpher Erfahrung, den sie als "quasi-mimetic evocation of ,real-life' experience" umschreibt. ${ }^{578}$ Der Leser vermag durch die experientiality, bzw. deren kognitive Parameter embodiment, Intention, Zeit und emotionale Evaluation des Geschehenen, einen Bezug zwischen der dargestellten Welt und seinem eigenen Erleben herzustellen.579

Mit diesem Verständnis können die Grenzen von Narrativität quer zu den formalistisch etablierten gezogen werden, die den Fokus auf die Struktur des Textes selbst legen. ${ }^{580}$ Narrativität ist hier nicht mehr an die möglichst lückenlose kausale Verknüpfung von events oder an die Erzählinstanz gebunden. Die prototypische Erzählung ist nicht dem Vorbild des Märchens nachgeahmt wie Marie-Laure Ryans simple narrativity, sondern gleichsam den Gegebenheiten, den "naturally occuring forms of storytelling“ selbst. ${ }^{581}$ Damit richtet sich Fludernik mit Bezug auf Käte Hamburger an der Fiktionalität aus. Bewusstseinsdarstellungen erhalten bei Fludernik entsprechend einen hohen

577 So John Pier, der die Studie „one of the founding documents of cognitive narratology“ nennt. John Pier, „Two Decades after the Publication of Monika Fludernik's „Towards a ,Natural Narratology": Introduction to the Forum", Partial Answers: Journal of Literature and the History of Ideas 16, Nr. 2 (2018): 239, https://doi.org/10.1353/pan.2018.0014. 2016 wurden Fludernik an der International Conference on Narrative 2016 zwei Panels gewidmet und die Beiträge gedruckt: Partial Answers: Journal of Literature and the History of Ideas, 16.2 (Juni 2018). David Herman sieht schon die Wirkungsästhetik Wolfgang Isers als Vorgänger der kognitiven Narratologie. Grundideen seien schon bei Roman Ingarden vorhanden. Vgl. David Herman, „Cognitive Narratology“, in The Living Handbook of Narratology, hg. von Peter Hühn u. a. (Hamburg: Hamburg University, 2013), Abs. 7, https://www.lhn.unihamburg.de/node/38.html.

578 Fludernik, Towards a „Natural“ Narratology, 9. Vgl. auch: „I here argue that narrativity is a function of narrative texts and centres on experientiality of an anthropomorphic nature." Fludernik, 26.

579 Für eine konzentrierte und kritische Diskussion vgl. Marco Caracciolo, „Experientiality“, in The Living Handbook of Narratology, hg. von Peter Hühn u. a. (Hamburg: Hamburg University, 2018), http://www.lhn.uni-hamburg.de/article/experientiality.

Vgl. auch Monika Fludernik, „Towards a ,Natural' Narratology Twenty Years After“, Partial Answers: Journal of Literature and the History of Ideas 16, Nr. 2 (2018): 329-347, https://doi.org/10.1353/pan.2018.0023.

580 Monika Fludernik, „Experientiality“, in Routledge Encyclopedia of Narrative Theory, hg. von David Herman, Marie-Laure Ryan und Manfred Jahn (London: Routledge, 2010).

581 Fludernik, Towards a „Natural“ Narratology, 16. 
narrativen Stellenwert, im Gegensatz zu historiografischen und summarischen Darstellungen, die für die story-orientierte Narratologie zentral waren. ${ }^{582}$

Um dem Vorwurf zu entgehen, mit ihrer Wortwahl des ,natürlichen Erzählens die unrühmliche normative Grenze zwischen dem Natürlichen und dem Unnatürlichen erneut zu etablieren, deren Unhaltbarkeit die Dekonstruktion gezeigt hat, macht Fludernik die drei Theorien explizit, auf die sie sich mit ihrem Konzept bezieht: Wiliam Labovs Untersuchungen über alltägliche Formen spontanen Erzählens, die Frame-Theorie mit ihren Ursprüngen in der Prototypentheorie und Jonathan Cullers Konzept der naturalization. Die Funktion der natural narrative liegt darin, einen Referenzrahmen zu bilden, um Erzählen als solches überhaupt erst verstehen zu können.

The major theoretical function of natural narrative in this study consists in supplying a prototype for the constitution of narrativity. Moreover, natural narrative, it is argued, operates as one central productive pattern of cognitive origin which regulates the textual production and reception of new naturally non-occuring discourse types and modes. ${ }^{583}$

Für den kognitiven Prozess der Rezeption von Erzählungen geht Fludernik von einem Vier-Ebenen-Modell aus, wobei auf jeder Ebene jeweils bestimmte frames aktiv sind. ${ }^{584}$ Hierbei referiert sie deutlich auf Paul Ricoeurs Konzept einer dreiteiligen Mimesis. Level I besteht aus den „axiomatic natural parameters of real-life experience " und bildet die basale kognitive Ebene. Mit diesen Parametern sind die internalisierten Konzepte von Handlungsmacht (agency), Intention, emotionale Evaluation, Motivation und anderen gemeint. Level II bezieht sich auf die narrative Vermittlung. Fludernik unterscheidet zwischen den Schemata telling, viewing, reflecting, experiencing und acting zur Konzeptualisierung der Dimensionen der Vermittlung. Im Grunde transportieren diese Kategorien die genetteschen Unterscheidungen Fokalisierung, Modus und Perspektive in einen kognitiven Kontext. In level III geht es um die verschiedenen Genres und Erzählformen („kinds or types of narration“) und deren „large-scale cognitive frames“. ${ }^{585}$ Level IV betrifft die narrativization. Fludernik beschreibt damit die Lese-Strategie für Texte, die in den übrigen frames nicht

582 "It is therefore prototypical historiography and prototypical fiction which are at odds on the issue of experientiality, and individual novels or histories may obey rules of their own." Fludernik, 25.

583 Fludernik, 16.

584 Hier ist auch Wolf Schmids Modell zu erwähnen, das ebenfalls vierstufig konzipiert ist. Es führt vom Geschehen zur Geschichte, zur Erzählung und schließlich der Präsentation der Erzählung. Vgl. Schmid, Elemente der Narratologie, 382-425.

585 Fludernik, Towards a „Natural“ Narratology, 44. 
als Erzählung rezipiert werden können, weil ihnen gewisse Kriterien fehlen: „Level IV constitutes an all-embracing dynamic process engendered by the reading experience. ${ }^{586}$ Wenn nicht klar ist, ob ein Text eine Erzählung ist und wie er in einen sinnvollen Kontext gestellt werden kann, tritt der Prozess der narrativization in Kraft. Mit diesem Neologismus bezieht sich Fludernik explizit auf Jonathan Cullers naturalization, das den Prozess umschreibt, wie eigenartige und unverständliche Phänomene in einen Erklärungszusammenhang gestellt werden können. ${ }^{587}$ Dieses Konzept ermöglicht es Fludernik, die Konventionalisierung von Erzähltechniken und Erzählinhalten zu erfassen, insbesondere die Anpassung der frames an Texte, die neue narrative Formen und Wahrnehmungen erproben. Irgendwann ist es nicht mehr notwendig, den

586 Fludernik, 45 .

587 Jonathan Culler entwickelte dieses Konzept im Rahmen seiner an die Dekonstruktion angelehnten Arbeiten. Vgl. seine Definition: „Naturalisation emphasizes the fact that the strange or deviant is brought within a discursive order and thus made to seem natural.“ Culler, Structuralist Poetics, 137. Während Cullers naturalization durchaus auch ein kritischer Begriff ist, gebraucht ihn Fludernik rein deskriptiv. Culler weist darauf hin, dass in Fluderniks narrativization eine Spannung zwischen dem Modell und der Interpretation des Lesers bestehe; die Gefahr bestünde, dass Texte zu einfach naturalisiert würden mit der Rechtfertigung der kognitiven frames: „This is perhaps only to say that there is a difference between narratology, an account of the structures that enable us to read and understand narrative, albeit at the cost of ignoring oddities and going with the flow of so-called ,natural' frames, and a hermeneutics that wants to show how particular narratives really work, what they really do or signify." Jonathan Culler, „Naturalization in "Natural“ Narratology“, Partial Answers: Journal of Literature and the History of Ideas 16, Nr. 2 (2018): 249, https://doi.org/10.1353/pan.2018.oo15. Was Culler mit „really do or signify“ meinen dürfte, ist gerade jenes Inkommensurable, das er in seinen dekonstruktivistischen Lektüren verfolgte. Zu erwähnen bleibt auch, dass Culler durchaus auch Naturalisierungsebenen vorsieht, die mit Fluderniks Ebenen-Modell in Verbindung gebracht werden können: „To naturalize at these various levels is to make the text intelligible by relating it to various models of coherence." Culler, Structuralist Poetics, 159.

Dazu sei Fludernik ausführlicher zitiert: „In my reading [...] narrativization applies one specific macro-frame, namely that of narrativity, to a text. When readers are confronted with potentially unreadable narratives, texts that are radically inconsistent, they cast about for ways and means of recuperating these texts as narratives motivated by the generic markers that go with the book. They therefore attempt to re-cognize what they find in the text in terms of the natural telling or experiencing or viewing parameters, or they try to recuperate the inconsistencies in terms of actions and event structures at the most minimal level. This process of narrativization, of making something a narrative by the sheer act of imposing narrativity on it, needs to be located in the dynamic reading process where such interpretative recuperations hold sway." Fludernik, Towards a „Natural" Narratology, 25. 
Prozess der narrativization bei bestimmten Techniken zu aktivieren, weil sich die kognitiven Strukturen an die neuen Verfahren angepasst haben. ${ }^{588}$

Inwiefern Fluderniks Modell radikal konstruktivistisch ist, indem es davon ausgeht, dass Narrativität erst vom Leser hergestellt wird, ist umstritten. ${ }^{589}$ Fludernik jedenfalls betont die universelle Gültigkeit der Parameter des level I. Dass erst auf der Ebene der Vermittlung kulturspezifische Erzählweisen zum Tragen kommen, hat zu Kritik geführt. ${ }^{590}$ Fludernik beschreibt das Was der Narration, die story, als Repräsentation von experientiality und das Wie, den discourse, als auf der Vermittlung durch Bewusstsein basierend: „, $[\mathrm{N}]$ atural' narratology bases itself on a very specific definition of narrative which is thematically identified as the representation of experienciality. Formally $[\ldots]$ one can now claim that all narrative is built on the mediating function of consciousness. “591

Dieses Modell hat den großen Vorteil, dass es Narrativität nicht mehr auf eine bestimmte Weise an miteinander verknüpfte events binden muss. Narrativität wird weder an der story noch am Erzähler festgemacht. ${ }^{592}$ So kann Fludernik der Intuition gerecht werden, dass auch hochgradig experimentelle Texte wie etwa Becketts Sprechtheater über mehr Narrativität verfügen als beispielsweise die berühmte Minimalgeschichte bei E. M. Forster, der Fludernik

588 Den Prozess der narrativization versucht Fludernik später konkret an kognitionswissenschaftliche Begriffe und Theorien anzubinden. Sie verknüpft sie mit der blending theory, die die These vertritt, dass „unnatürliche“ Elemente in einer Erzählung über das blending zweier schon bekannter frames naturalisiert werden. Vgl. Monika Fludernik, „Naturalizing the Unnatural. A View from Blending Theory“, Journal of Literary Semantics 39, Nr. 1 (Januar 2010): 1-27, https://doi.org/10.1515/jlse.2010.001. Eines ihrer zahlreichen Beispiele ist die Erzählung des Sterbens aus der Ich-Perspektive, ein im Grunde unmöglicher Vorgang, der dadurch verständlich wird, dass er als eine Überblendung des frame des Erlebens des Todes und demjenigen des allwissenden Erzählers, der dieses Erleben beschreiben kann, verstanden wird. Diese Überblendungen werden mit der Zeit konventionalisiert und generieren neue Typen des Erzählens. Vgl. Fludernik, 17f. Diese These der Konventionalisierung wurde kontrovers aufgenommen. Vgl. dazu Pier, „Two Decades after the Publication of Monika Fludernik's Towards a ,Natural' Narratology“.

589 Vgl. Caraciollo: „[D]epending on how we construe the term ,evocation; Fludernik's definition seems to hover between the textualist orientation of structuralist narratology and the readerly orientation of postclassical, and specifically cognitive, approaches." Caracciolo, „Experientiality“, Abs. 8. Dagegen Fludernik selbst: „The general framework for the theory is a constructivist one. Readers actively construct meanings and impose frames on their interpretations of texts just as people have to interpret real-life experience in terms of available schemata." Fludernik, Towards a "Natural" Narratology, 9.

590 vgl. Jan Alber, „Natural Narratology“, in Routledge Encyclopedia of Narrative Theory, hg. von David Herman, Marie-Laure Ryan und Manfred Jahn (London: Routledge, 2010).

591 Fludernik, Towards a „Natural“ Narratology, 49.

592 „I emphatically refuse to locate narrativity in the existence of a narrator.“ Fludernik, 26. 
als „report-like narrative“, das über keine experientiality verfügt, einen geringen Grad an Narrativität bescheinigt. ${ }^{593}$

Eine grundsätzliche Problematik der Theorie Fluderniks besteht jedoch offensichtlich darin, dass sie auf dem ,natürlichen' Vorkommen von Erzählen basiert, das für viele avantgardistische Texte keine Referenz ist. Der Fokus auf der narrativization führt zurTendenz, die einer Interpretation widerstrebenden Erzählungen über einen Kamm zu scheren und sie so ihrer Devianz zu berauben. So gibt es Erzählungen, die sich sowohl der narrativization als auch der Konventionalisierung verwehren, wie die hier behandelten, die prekär bleiben, weil diese Prekarität die Konstitution derselben bildet. Auf diese Problematik weist auch die unnatural narratology hin, die den Fokus auf das Normverletzende und Normerweiternde von Erzählungen legt. ${ }^{594}$

\subsection{Unnatural Narratology}

Brian Richardson brachte mit seiner Studie Unnatural Voices zehn Jahre nach dem Erscheinen von Fluderniks Thesen das Gegenstück zu Towards a,Natural Narratology in die Diskussion ein: die unnatural narratology. 595 Obwohl vom Begriff her diese gegensätzliche Stoßrichtung betont wird, wollen die Exponenten der unnatural narratology diese komplementär verstanden wissen und betonen die Nähe zu Fluderniks Modell.596 Der Begriff der unnatural

593 Forster definiert story und $p l o t$ folgendermaßen: „We have defined a story as a narrative of events arranged in their time-sequence. A plot is also a narrative of events, the emphasis falling on causality. ,The king died and then the queen died,' is a story. ,The king died, and then the queen died of grief“ is a plot." E. M. Forster, „The Plot“, in Aspects of the Novel (New York: Harcourt, Brace and Company, 1927), 13 .

594 So auch in der Verwandtschaft zum Begriff "queer", die die Exponenten betonen. Vgl. Jan Alber und Rüdiger Heinze, „Introduction“, in Unnatural Narratives - Unnatural Narratology, hg. von Jan Alber und Rüdiger Heinze (Berlin, Boston: De Gruyter, 2011), 3.

595 Brian Richardson, Unnatural Voices. Extreme Narration in Modern and Contemporary Fiction (Columbus: Ohio State University Press, 2006). In der Regel wird im Folgenden der englische Ausdruck unnatural verwendet, um den Theoriehintergrund deutlich zu machen. Was Fludernik in der Herleitung ihres Begriffs natural geschrieben hat, es handle sich nicht um eine Reaktualisierung von normativ aufgeladenen Begrifflichkeiten, gilt auch für den Term unnatural. Zu bemerken ist, dass Richardson 1998, also zwei Jahre nach Erscheinen von Fluderniks Towards a „Natural“ Narratology, noch von einer „Antinarratology“ spricht, die entwickelt werden müsse. Brian Richardson und David Herman, „A Postclassical Narratology“, PMLA 113, Nr. 2 (1998): 289, https://doi. org/10.2307/463366.

596 "Nevertheless, we would all like to describe the relationship between Fludernik's ,natural narratology and our unnatural narratology in terms of complementarity. For us, the 
narratology hat sich mittlerweile in zahlreichen Studien und Sammelbänden verbreitet und verfügt auch über Handbuch- und Lexikoneinträge. ${ }^{597}$ Er zielt darauf, den marginalisierten experimentellen und fantastischen Formen des Erzählens einen angemessenen Platz in der Narratologie zuzuweisen und den Kanon der Narratologie somit zu erweitern: „Unnatural narratologists also point out that narrative theory has had a mimetic bias ever since the times of Aristotle and the unities of time, place, and action. And this real-world orientation has lead to the marginalization of the unnatural. ${ }^{\text {“598 }}$

Die unnatural narratology stellt auch hinsichtlich der Systematik eine Alternative zu Fluderniks Modell dar. Es wird Wert darauf gelegt, dass die unnatural narratology kein geschlossenes Modell liefert. Die Notwendigkeit der Abweichung von einem umfassenden und ganzheitlichen Modell, was normalerweise gerade als Qualität einer Theorie gilt, wird betont: „However, we do not mean to replace existing unified theories so much as to supplement them as we rescue the types of narratives that are left out by the dominant theories. “599

Bei aller Differenz der verschiedenen Ansätze besteht die gemeinsame Basis der unnatural narratology im Interesse an "narratives that have a defamiliarizing effect because they are experimental, extreme, transgressive,

unnatural and the natural are equally important.“ Jan Alber u. a., „What Is Unnatural about Unnatural Narratology? A Response to Monika Fludernik“, Narrative 2o, Nr. 3 (2012): 380, https://doi.org/10.1353/nar.2012.0020.

597 Vgl. dazu Herman und Vervaeck: „Unnatural narratology has become one of the most prominent recent developments in narrative theory." Luc Herman und Bart Vervaeck, "How Unnatural Does It Get?“, Style 50, Nr. 4 (2016): 514, https://doi.org/10.1353/ sty.2016.0042.

598 Alber und Heinze, „Introduction“, 5 .

599 Alber u. a., „What Is Unnatural about Unnatural Narratology?“, 375. Vgl. dazu auch die gegenseitigen Bezugnahmen in Narrative 20, Nr. 3 (2012). Monika Fludernik kritisiert zu Recht einige Unklarheiten an der unnatural narratology. Sie hebt deren Nähe zur, natural narratology hervor und fragt kritisch nach den Unterschieden zu herkömmlichen „postmodernist reading strategies of metafictionality, fantasy, contradictoriness". Und weiter: „Or, seen from a different perspective, does the ,unnatural' simply highlight the postmodernist and the fantastic both within and on the margins of realism and the mimetic?" Monika Fludernik, „How Natural Is ,Unnatural Narratology'; or, What Is Unnatural about Unnatural Narratology?", Narrative 20 (2012): 365, https://doi.org/10.1353/nar.2012.0o19. Des Weiteren weist sie darauf hin, dass mit dem Begriff unnatural eine fragwürdige Dichotomie eingeführt wird, die sie mit einer breiten Diskussion und Herleitung des Begriffs natural umgehen wollte. Die Frage nach der Methodik und der Abgrenzung gegenüber anderen postmodernen Theorien werden von den Vertretern der unnatural narratology verschieden geklärt; die Kritik an der Dichotomie des Begriffs veranlasst sie meist dazu, die „decidedly positive connotation“ ihrer Analysen zu betonen. Alber u. a., „What Is Unnatural about Unnatural Narratology?", 374. Hervorhebung i. O. 
unconventional“.600 Diese weite Definition geht im Grunde nicht über Viktor Schklowskis Begriff der Verfremdung hinaus, der damit das Unnatürliche im Sinn einer entautomatisierten Sprache als Literarizität bezeichnete. ${ }^{601}$ Schklowski wird denn auch von Richardson als Gewährsmann herangezogen. ${ }^{602}$

Bei Jan Alber, der in seinem Ansatz für eine enge Definition von unnatural narratives plädiert, erfährt der Begriff eine starke Reduktion. Er beschränkt sich auf Texte, die, gemessen an den bekannten Gesetzen der Physik und der Logik, „physically or logically [], impossible scenarios and events" ${ }^{4603}$ darstellen. Alber konzentriert sich auf Texte der Postmoderne, zeigt aber auch, dass solche, unnatürlichen' Phänomene auch in früheren Epochen eine zentrale Rolle gespielt haben.

Im Rahmen dieser Studie ist die dritte, weitere Definition von unnatural narratives, die den Fokus auf die Frage der Mimesis in einem allgemeinen Sinn lenkt, am fruchtbarsten. ${ }^{604}$ Brian Richardson streicht in seiner Argumentation besonders heraus, dass unnatural narratives gängige Konventionen verletzen. Als zentrale Erzählkonvention nennt er erstens die Erzählstimme bzw. die Identität des Erzählers, zweitens die klare Trennbarkeit von story und discourse („a logically consistent fabula that is retrievable from the sujet“605) sowie die epistemologische Konsistenz („epistemic consistency“) der Figuren, die etwa darin besteht, dass eine Figur nicht wissen kann, was eine andere denkt. Mit dem ersten Punkt, der Frage nach dem Erzähler, zielt er auf Texte, in denen nicht klar ist, wer erzählt oder in denen die Erzählstimme wechselt. Richardson hebt besonders den Fall der „second-person narration“ hervor, die

\footnotetext{
6 oo Alber und Heinze, „Introduction“, 2.

601 Vgl. Schklowski: „Poesie müssen wir also als gebremste, verbogene Rede definieren. Poetische Rede ist konstruierte Rede.“ Viktor Schklowski, „Kunst als Verfahren“, in Die Erweckung des Wortes. Essays der russischen Formalen Schule, hg. von Fritz Mierau (Stuttgart: Reclam, 1991), 31.

$6 \mathrm{o} 2$ Richardson nennt als weitere Vorläufer Michael Bachtin („Polyphonie“), Käte Hamburger, Dorrit Cohn, Ann Banfield (Unspeakable Sentences), Sylvie Patron und Lubomir Dolezel (Possible World-Theory), vgl. Brian Richardson, „What Is Unnatural Narrative Theory?", in Unnatural Narratives - Unnatural Narratology, hg. von Jan Alber und Rüdiger Heinze (Berlin, Boston: De Gruyter, 2011), зо.

603 Alber, „Diachronic Development of Unnaturalness“, 41.

604 "The basic insight of scholars working within the framework of unnatural narratology is that narratives do not only mimetically reproduce the world as we know it. Many narratives confront us with strange narrative worlds which rely on principles that have very little to do with the actual world around us." Alber und Heinze, „Introduction“, 5.

605 Richardson, „What Is Unnatural Narrative Theory?“, 23.
} 
grundsätzlich logische Schwierigkeiten bereithält. ${ }^{606}$ Mit dem zweiten Punkt visiert er Texte an, die selbstwidersprüchliche oder multiple stories beinhalten, einen unfixierten discourse haben oder denarrated sind. ${ }^{607}$ Ein extremes Beispiel von denarration ist Samuel Becketts Roman Molloy, in dem jeder Satz wieder zurückgenommen wird. ${ }^{608}$ Die epistemologische und ontologische Konsistenz als dritter Aspekt scheint meist ein Sonderfall vom ersten Punkt zu sein, weil sie besonders häufig in Fällen von first-person narration auftaucht.

Diese drei Kriterien von unnaturalness führt Richardson mit den Begriffen der Anti-Mimesis und des Anti-Realismus eng. Er unterstreicht damit die Verletzung der mimetischen und realistischen Normen im Unterschied zur Ablehnung derselben, wie es die Begriffe amimetisch oder unrealistisch denotieren würden. ${ }^{609}$ Damit betont er auch die Wichtigkeit des Bezugs der unnatural narrative zu den verletzten Parametern. ${ }^{610}$

606 „This confusion is inevitable because second-person narration is situated between but irreducible to the standard binary oppositions of either first and third person or heteroand homodiegetic narration; instead, it oscillates irregularly from one side to the other and cannot be convincingly ,naturalized' to either conventional practice." Richardson, 25.

Vgl. dazu auch Fludernik, Towards a „Natural“Narratology, 166-186.

Vgl. auch den Eintrag im Online-Lexikon: Jan Alber u. a., Hrsg., Dictionary of Unnatural Narratology, 2017, http://projects.au.dk/narrativeresearchlab/unnatural/undictionary/.

$6 \circ 7$ Vgl. dazu auch Richardson, „Denarration“.

608 Dieses Erzählen wird als „ontological denarration“ bezeichnet, weil es die Ontologie der erzählten Welt verletzt. Die andere Form der „existential denarration“, die den Verlust einer Lebensgeschichte und damit der Identität bezeichnet, ist in diesem Kontext nicht von Belang. Siehe Kap. 3.2.4 Digression als Aufschub, Ausweichen und Abweichen, S. 125 ff. oben.

6 o9 Diese Betonung des Unterschieds zwischen anti-mimetic und non-mimetic hat Richardson im Jahr 2000 noch nicht etabliert. Dies zeigt auch, was für ein dynamisches Feld die unnatural narratology ist. Vgl. Richardson, „Narrative Poetics and Postmodern Transgression. Theorizing the Collapse of Time, Voice, and Frame“. Dabei stellt sich jedoch die Frage, warum diese Überlegung nicht auch in die Definition des Begriffs der unnatural narratives einfloss und diese konsequent anti-natural narratives genannt werden.

610 Zur Präzisierung dieses Aspekts schreibt Richardson: „This point can be clarified by a glance at Tristan Tzara's play, The Gas Jet. This work is entirely unnatural and is irreducible to any conceptual framework. It simply contains several lines of nonsense dialogue spoken by pseudo-characters called, for no particular reason, ,Eye, 'Ear, ,Mouth, ,Eyebrow, etc. There is no allegory, no realism, no dreamlike qualities, and unlike the theater of the absurd, no sustained play with the conventions of human conversation. It is, significantly, rather boring and is understandably rarely staged. This suggests to me that unnatural elements function best in a literary context when framed by, combined with, or in a dialectical relation with other, natural' (that is, conventional) elements of narrative: the purely unnatural is perhaps not especially interesting. The conclusion I draw is that, when we analyze a play by Pinter, we should recognize the hints of allegory, the thematic associations, the suggestion of fantasy or dream-like events, the parody of 
Als Prototypen mimetischen Erzählens erwähnt Richardson Anna Karenina, weil dort die Fiktion sich an der Nachahmung realistischer, möglicher Ereignisse und Charaktere orientiert. Märchen begreift Richardson als amimetisch, weil es seiner Argumentation gemäß keinen Sinn macht, auf deren Widersprüchlichkeit zur realen Welt hinzuweisen. Die anti-mimetische Erzählung dagegen, so formuliert Richardson, wiederum an Schklowski erinnernd, „points out its own constructedness, the artificiality of many of its techniques, and its inherent fictionality“. ${ }^{\prime} 611$

Mit der unnatural narratology hat sich also ein aufsehenerregender und produktiver Forschungszweig herausgebildet, der sich grenzwertigen Fällen annimmt und weniger am großen, allumfassenden System interessiert ist. ${ }^{612}$ Während Richardson den unnatural narratives ihre Widerspenstigkeit belassen will und ihre Differenz zu Konzepten der klassischen Narratologie herausarbeitet, schlägt beispielsweise Alber einen Katalog von neun Lesestrategien vor, mit denen Sinn aus den Texten geschöpft werden kann, ohne sie in ihrer Eigenart zu beschneiden. ${ }^{613}$

Obgleich Fontanes Stechlin kaum als unnatural narrative angesehen werden kann, vermag hier deren spezifische Perspektivierung ein neues Licht auf den Text zu werfen. Wenn etwa die Verbindungen des Sees Stechlin zu tektonischen wie revolutionären Bewegungen nicht nur symbolisch, sondern auch wörtlich gelesen werden können, ist dies als auffälliger Einbruch des Übernatürlichen in ein realistisches Setting anzusehen, das dadurch in seinen

ordinary human interactions - but not reduce the unnatural elements to any one of these other aspects.“ Richardson, „What Is Unnatural Narrative Theory?“, 33. Mit dieser weiteren Klärung, die für gewisse Texte sicherlich wichtig ist, gerade wenn sie deutlich Bezug zu Intertexten nehmen, läuft man jedoch gleichzeitig wiederum Gefahr, dass man das „Unnatürliche“ als parasitäres Textphänomen begreift.

611 Richardson, 31.

612 Vgl. dazu die Formulierung bei Fludernik: „While I tend to concentrate on the overall taste [of the pudding; L. G.], ignoring some of the ingredients, Alber et al. savour the tinge of spice that conflicts with the overall familiar blandness of the pudding." Fludernik, „How Natural Is ,Unnatural Narratology'; or, What Is Unnatural about Unnatural Narratology?", 362 . Vgl. die Affirmation in Alber u. a., „What Is Unnatural about Unnatural Narratology?", 38o.

613 Jan Alber, „Unnatural Narratology. The Systematic Study of Anti-Mimeticism“, Literature Compass 10, Nr. 5 (2013): 449-46o. In dieser Hinsicht lässt sich ein Bezug der Vertreter der unnatural narratives zur Position von Moritz Baßler herstellen, der die „Unverständlichkeit“ der Prosa mit modernistischen Verfahren der Textur als Phänomen insbesondere der emphatischen Moderne versteht: „Texturierte Texte machen Sinn. Sie machen Sinn auf eine Weise, die unsere gewohnten Sinnerwartungen unterläuft. Ihre Bedeutung läßt sich immer nur für Momente feststellen, nie auf Dauer festlegen. Damit bleibt die Kunst der klassischen Moderne für uns eine intellektuelle und ästhetische Herausforderung." Baßler, Die Entdeckung der Textur, 195 . 
Grundfesten erschüttert würde. ${ }^{614}$ Ähnliches gilt für den roten Hahn, der in der geistreich-ironischen Rede Dubslavs unter dem Eis des Sees schlummert. Andere Aspekte ,unnatürlichen` Erzählens finden sich in den Erzählverfahren. So ist das Oszillieren zwischen einem omnipotenten Erzähler, der Kenntnis vom Innenleben der Figuren hat, und einer internen Fokalisierung auf einzelne Figuren durchaus ein ,unnatürliches' Verfahren zu nennen, wenn es auch verbreitet und in diesem Sinn konventionalisiert ist. Weiter scheint auch die überdeutliche Kontrolle von Ambivalenzen und deren Auflösung und unmittelbare Ablösung durch neue Ambivalenzen, welche die Künstlichkeit des Ordnungsverfahrens ausstellen, ein Verfahren zu sein, das durchaus als unnatural gelten kann.

Bei Robert Walser liegt es auf der Hand, dass sein Erzählen als ,unnatürlich verstanden werden kann, ist es doch hochgradig widersprüchlich, durchsetzt von Unstimmigkeiten, Metalepsen und Digressionen. Auch Kafkas Bau mit der paradoxen Zeitstruktur und dem in seiner Spezies ambivalent konnotierten Erzähler kann als ,unnatürliches‘ Erzählen bezeichnet werden, auch insofern der Text Fluderniks kognitive real-life Parameter Lügen straft. ${ }^{615}$

Das prekäre Erzählen Walsers, Kafkas und auch Fontanes lässt sich also durchaus als ,unnatürlich im diskutierten Sinn beschreiben. Bei Fontane wird durch überdeutliche Führung des Erzählers Ambivalenz in der Anwendung so kontrolliert eingegrenzt, dass in der Künstlichkeit dieser Kontrolle eine tiefergehende Prekarität greifbar wird. In Walsers Texten ist es die Befreiung des discourse, der performativ stories entwirft, die den prekären Status verantwortet. Kafka dagegen gestaltet eine prekäre Ordnung in einer eigentlich unmöglichen, weil paradoxen Erzählsituation. Bei Walser und Kafka wird Ordnung als Erzählordnung bewusst untergraben. Insofern scheint sich das prekäre Erzählen der beiden als antinarrative darzustellen, als ein Erzählen, das einen ,Angriff' auf das Erzählen ausführt.

614 Interessanterweise sieht Fludernik gerade darin den Vorteil der unnatural narratology, dass diese das Übersinnliche in der realistischen Literatur ins Zentrum rückt: „An analysis of how modern(ist) our empirical resistance to the fantastic is could help to foreground the intrinsic reliance of realism and of the mimetic on what is not usually regarded as ,natural.' Not only is realism illusionary, but the mimetic reproduces both that which is natural and fictional scenarios that are non-natural.“ Fludernik, „How Natural Is ,Unnatural Narratology'; or, What Is Unnatural about Unnatural Narratology?“, 368.

615 Vgl. Brian Richardson, der Tier-Erzähler als unnatural narrator beschreibt: Richardson, „Narrative Poetics and Postmodern Transgression. Theorizing the Collapse of Time, Voice, and Frame", 33. 


\subsection{Antinarratives?}

Antinarratives werden im Dictionary of Unnatural Narratology definiert als „flagrant forms of unnatural narratives which violate conventional narrative practices; such works may have contradictory chronologies, collapsed narrative voices, or extremely opaque discourse“. ${ }^{616}$ Diese Beschreibung deckt sich mit der Definition des Begriffs der Anti-Mimesis bei Richardson: Es wird unterstrichen, dass die Texte in engem Bezug zu konventionellen Formen stehen, die sie verletzen. Der Begriff antinarrative taucht zuerst in Seymour Chatmans Story and Discourse auf, wo das Infragestellen der narrativen Logik das Zentrum der Definition bildet. ${ }^{617}$ Gerald Prince referiert auf Chatman und definiert den Begriff in seinem Dictionary wie folgt: „A (verbal or nonverbal) text adopting the trappings of narrative but systematically calling narrative logic and narrative conventions into question“. ${ }^{618}$ Wie erwähnt, betont Ryan den geringen Grad an Narrativität der antinarrative und die Schwierigkeit, eine stabile und umfassende Interpretation zu erzeugen. ${ }^{619}$

Im Zentrum der letzten zwei Definitionen steht die story. Richardson scheint keinen nennenswerten Unterschied zwischen der Definition von anti-mimetic,

616 Jan Alber u. a., „Anti-Narrative“, in Dictionary of Unnatural Narratology, 2017, http:// projects.au.dk/en/narrativeresearchlab/unnaturalnarratology/dictionaryofunnaturalnar ratology/antinarrative/.

617 Chatman schreibt in Bezug auf Jorge Luis Borges' Text Eljardín de senderos que se bifurcan: „In a genuine sense such texts may be called , antinarratives; since what they call into question is, precisely, narrative logic, that one thing leads to one and only one other, the second to a third and so on to the finale." Chatman, Story and Discourse, 57 . Wie in diesem Zitat kenntlich ist, scheint Chatman den Begriff auf die Zeitstruktur und die kausale Verknüpfung der events zu beschränken.

618 Prince, A Dictionary of Narratology, 6. Bei Seymour Chatman ist der Unterschied zu den nonarrated narratives, also Texten, die über keinen, respektive einen unmarkierten Erzähler verfügen, wichtig. Typischerweise wird hierfür Ernest Hemingways Erzählen mit dem Fokus auf das Erleben der Figuren genannt.

619 Ryan, „The Modes of Narrativity and Their Visual Metaphors“, 379. Richardson plädiert gerade für eine Offenheit der Lektüren und warnt davor, Texte mit einer alles erklärenden Interpretation einzuengen: „The conclusion I draw is that when we analyze an unnatural work, we should recognize the hints of allegory, the thematic associations, the suggestion of fantasy or dreamlike events, the parody of ordinary human interactions - but not reduce the unnatural elements to one or two of these other aspects in an effort to place the entire work safely within a single totalizing interpretation." Brian Richardson, Unnatural Narrative. Theory, History, and Practice (Columbus: Ohio State University Press, 2015), 21. 
unnatural narratives und antinarratives zu machen. ${ }^{620}$ Wie für Ryan ist auch für ihn die story die zentrale Referenz für die Definition von Narrativität:

[T]he unnatural refers to the story, not the discourse. That is, we need to ask whether the events, figures, and framing are mimetic or not, rather than how much the presentation of those figures and events differs from that of a natural or conventional narrative. ${ }^{621}$

I propose that narrative is most usefully considered as the representation of a causally related series of events. ${ }^{622}$

So markiert der Vorsatz "anti-“ einen Grenzbereich, der gleichzeitig Exklusion und Inklusion aus der Menge der erzählenden Texte bedeutet. ${ }^{623}$ Das „anti-“ denotiert in Richardsons Verständnis einen Angriff auf die story im strukturalistischen Sinn als eine kausal verknüpfte Reihung von Ereignissen. Entsprechend werden antinarratives von ihren Defiziten gegenüber dieser engen Definition des Erzählens bestimmt: keine story, keinen plot, keine Charaktere, statt dessen eine unlogische erzählte Welt. ${ }^{624}$ Gemäß Richardson

620 Vgl. dazu Brian Richardson, „Anti-Narrative“, in Routledge Encyclopedia of Narrative Theory, hg. von David Herman, Marie-Laure Ryan und Manfred Jahn (London: Routledge, 2010); Richardson, „What Is Unnatural Narrative Theory?“

621 Richardson, Unnatural Narrative. Theory, History, and Practice, 21.

622 Richardson, 52 .

623 Ryan verortet die antinarratives am äußersten Rand ihres Spektrums der Narrativität. Die nachfolgenden Modes Nr. 11 und Nr. 12 beschreiben keine weitere Abnahme von Narrativität, sondern sind mediale Ausdifferenzierungen. Mit diesen Kategorien will Ryan zeigen, dass sich ihr Konzept nicht auf literarische Texte beschränkt: „[The] concept of mode of narrativity is not limited to literary text". Ryan, „The Modes of Narrativity and Their Visual Metaphors", 380 .

624 Vgl. dazu Fludernik, die argumentiert, dass das Konzept story für die Literatur der Moderne kaum angemessen ist: „Events and stories are simply no longer central to the focus of what these texts are about. An obvious theoretical conclusion to this problem is of course simply to deny the label narrative to the bulk of twentieth-century fictions, to say, that is, that the norm for twentieth-century fiction is no longer instantiated by the narrative discourse type. The predominantly negative characterization of experimental fiction as contravening traditional story parameters (no plot, no character, no teleology, etc.) points in this direction, as do formulations on the lines of the ,death of the author." Fludernik, Towards a „Natural“ Narratology, 252. Fludernik kann an dieser Stelle ihr Konzept der experientiality in Anschlag bringen. Jedoch findet auch dieses seine Grenzen dort, wo die narrativization nicht mehr über Fluderniks frames der real-life parameters funktioniert: „I have, however, eschewed generalizing statements about the potential usefuleness (or lack thereof) of postmodernist writing techniques, particularly in the attempt to transcend the current descriptive terminology, which is mostly of a negative kind: no plot, no setting, no characters. Nevertheless, at the point where natural parameters, even stretched to their utmost, no longer help to narrativize certain experimental 
ist es dieses Defizit, das als Gegenbewegung einen Angriff auf das Erzählen als solches darstellt. Die Devianz der antinarratives ist sozusagen ihre Waffe.

Auch wenn in der Definition des Dictionary of Unnatural Narratology der Fokus nicht auf die story gelegt wird und dem Grundsatz der unnatural narratology entsprechend solches Erzählen nicht defizitär verstanden werden soll, lässt sich die Ausrichtung des Begriffs antinarrative auf die Destruktion des Erzählens sowie die teilweise Gleichsetzung von Erzählung und story beobachten. Es wird impliziert, dass es in den Texten hauptsächlich darum gehe, sich gegen das Erzählen zu richten. Diese Argumentation macht wiederum eine gewisse Form des Erzählens zum Standard. Ausgangspunkt ist die Vorstellung einer Art reinen Erzählens, wie es bei Ryan die simple narrativity verkörpert. Wenn es auch anti-narrative Texte gibt, die aus dem Antrieb entstehen, gewisse Erzählelemente aufs Korn zu nehmen, zu persiflieren, dekonstruieren und subvertieren, heißt dies nicht, dass es allen Texten solcher Erzählweise darum geht. In der Mehrzahl dürfte der Impetus dieser Texte im Erzählen selbst liegen, im Stoff, für den es eine adäquate Form braucht, die dann in ihrer Wirkung anti-narrativ daherkommt, zuallererst aber narrativ ist.

Der Vorbehalt gegenüber dem Konzept der antinarrative gründet also auf zwei Einwänden. Zum einen scheint es eine zu enge Definition zu sein, die story als mehr oder weniger kausale Verkettung von events zur Grundlage von Narrativität zu erklären. Zum anderen ist die Betonung der Aggressivität und der negativen Definition mit dem Präfix ”,anti-“, das auf das parasitäre Verhalten hinweist und eine selten direkt vorhandene Intention dieser Texte unterstellt, nicht angemessen. Lässt sich Fontanes Stechlin noch als ansatzweise unnatural narrative lesen, so kaum als antinarrative. Dennoch hat Der Stechlin mit Walser und Kafka sehr viel zu tun, was durch das Präfix „anti“ unnötigerweise verschleiert wird. Die narrativen Formen, die Walser und Kafka entwickeln und akzentuieren, zitieren herkömmliche Formen und setzen sich mit deren Ordnungen auseinander. Gleichwohl ist es wenig sinnvoll, sie auf diesen Aspekt der Subversion zu reduzieren.

Der Begriff des prekären Erzählens bietet in dieser Hinsicht eine Alternative. Indem die Texte an das Ordnungsproblem der Moderne angebunden werden, wird ihre Reflexion auf Ordnung und Ordnungsverfahren deutlich. Dass darin konventionelle Erzählverfahren subvertiert werden, ist nicht die Absicht, sondern eine Wirkung davon. Prekär sind die dargestellten Ordnungen im Text und das Erzählen selbst, das ein Bewusstsein von Künstlichkeit und Konstruktion der Narration kennzeichnet und dieses ausstellt. Die Analyse der

texts, Natural Narratology will ultimately have to yield to a different model that is of a more poststructuralist orientation." Fludernik, 314. 
Texte aller drei Autoren hat die Bedeutung des discourse für die Ordnungsherstellung verdeutlicht. Das prekäre Erzählen betont, wie sehr discourse und story auch in dieser Hinsicht fundamental verstrickt sind. Der discourse kann eine sehr komplexe und unübersichtliche story als geordnet darstellen und eine eigentlich simple story unter Einbezug diverser Erzähltechniken als hochkomplex oder chaotisch ausweisen. Dennoch lässt sich, wenn die Erzählstimme als Urheber des Textes paradox oder eine weitere Ebene als Erzählgeschichte akzentuiert wird, die story auch nicht mehr vorbehaltlos rekonstruieren. ${ }^{625}$ So zeichnet sich dieses Erzählen dadurch aus, dass sowohl story als auch discourse im Zusammenspiel ihrer Ordnung und Herstellung von Ordnung prekär werden.

\subsection{Prekäres Erzählen. Fazit}

Das prekäre Erzählen aktiviert zwar zahlreiche Modi der Erzählhaftigkeit, wie Ryan sie etabliert, jedoch ist die Zuordnung wenig aussagekräftig. Die Betonung der story und die damit einhergehende defizitorientierte Beschreibung des Erzählens hebt Fludernik in ihrer, natural' narratology auf. Der Fokus auf das ,natürliche‘ Erzählen ist jedoch seinerseits problematisch. Das Prekäre des Erzählens lässt sich im Prozess der narrativization gerade nicht auflösen, da es konstitutiv für diese Texte ist. Vor diesem Hintergrund liegt eine Anschließbarkeit des prekären Erzählens an die unnatural narratives oder antinarratives auf der Hand. Offenkundig ist dies bei Kafka und Walser. Die widersprüchliche Zeitstruktur, die ambivalente Spezies des Erzählers und die zwischen Iteration und Singulation changierende Erzählweise in Der Bau sowie die zahlreichen denarrations, metanarrativen Sequenzen und das performative Erzählen bei Walser legen Zeugnis davon ab. Im Falle von Fontanes Stechlin bestimmt die Interpretation darüber, ob etwa der See als übersinnliches Element verstanden wird, welches das realistische Setting in ambivalente Schwingung bringt oder ob der rote Hahn im See wörtlich genommen wird. Hinzu kommen das Oszillieren zwischen einem omnipotenten und personalen Erzähler, die wechselnden Fokalisierungen, die als ,unnatürliche` Elemente gelesen werden

625 Auch beim Konzept der unnatural narratives trägt der discourse zur Beschreibung einer Erzählung als „unnatürlichem“ Erzählen bei. Insofern ist an Fluderniks Vorwurf, dass die unnatural narratology ohne Not binäre Oppositionen wie die zwischen natural und unnatural zementiere, durchaus bedenkenswert. In Fluderniks Modell ist die story nur ein frame im Prozess der narrativization. Vgl. die schon oben erwähnte Debatte: Fludernik, „How Natural Is ,Unnatural Narratology; or, What Is Unnatural about Unnatural Narratology?"; Alber u. a., „What Is Unnatural about Unnatural Narratology?“ 
können, sowie die fehlende Motivierung zahlreicher Ereignisse durch die story. Es ist aufschlussreich zu beobachten, wie der Realismus zur Etablierung seiner Poetik auf das ,Unnatürliche' angewiesen ist.

Der Begriff der unnatural narratives impliziert die Verletzung herkömmlicher Ordnungen. Aus einer kognitivistischen Perspektive ist dasjenige ,unnatürlich', was nicht in den üblichen frames naturalisiert und erzählbar gemacht (narrativized) werden kann. Dort, wo verschiedene kognitive frames aktiviert werden müssen, wird deutlich, dass die Ordnung des Textes nicht mit dem mentalen ,natürlichen' Modell einer Erzählung übereinstimmt, wie es hier vor allem für Walser und Kafka, aber auch für Fontane der Fall ist.

Das prekäre Erzählen ist also gleichzeitig weiter und enger als die antinarratives. Weiter ist es, weil das Hervorstreichen der Gegenbewegung wegfällt, also zunächst der Aspekt des Erzählens betont wird statt der des Anti-Erzählens. Enger ist das prekäre Erzählen insofern, als es die Ordnungsthematik miteinbezieht und damit Erzählen auch in einen größeren Kontext einbindet: Der Fokus auf die Ordnung ermöglicht es, die angesprochenen Aspekte auf den narrativen und symbolischen Ebenen zusammenzuführen und dieses Erzählen wiederum als Ordnungsleistung zu verstehen. 